\title{
TOURIST PERCEPTION OF VISITOR MANAGEMENT STRATEGY IN NORTH BANDUNG PROTECTED AREA
}

\author{
Ersy Ervina1, Shandra Rama Panji Wulung2 and Vany Octaviany3 \\ ${ }^{1,3}$ Telkom University, Indonesia \\ ${ }^{2}$ University of Education Indonesia, Indonesia \\ ersy@tass.telkomuniversity.ac.id
}

\begin{abstract}
Sustainable tourism is one of Djuanda Forest Park (Tahura) management goals in implementing a visitor management strategy in the North Bandung Protected Areas. Djuanda Forest Park is an important area to be preserved as a tourist destination because of its very strategic function for environmental sustainability in Bandung City and its buffer areas. The visitor management strategy's implementation level can be seen from the perception of tourist who comes to Djuanda Forest Park, which analyzes by the intensity of destination use, accessibility, and carrying capacity. Perception cannot be separated from the satisfaction of tourists when visiting. This study aims to analyze tourists' perceptions of the implementation of visitor management strategies together with tourist satisfaction in the Tahura protected area. The method used is descriptive with data collection techniques through questionnaires. The results showed that tourist perceptions and satisfaction with the Visitor Management Strategy application were quite good. In improving quality, management is expected to be able to design a more systematic flow of visits and limit the number of visits for each tourist area to minimize the impact of tourism activities on the environment. On the satisfaction side, managers need to improve product and service quality, especially the preservation of tourist areas to create tourists experience
\end{abstract}

Keywords: Tourists Perception; Visitor Management Strategy; Tourists Satisfaction.

\section{INTRODUCTION}

Protected areas have an important function and role in sustainable development. The designation of protected areas aims to prevent the devastation of natural resources and provide economic benefits for the community (Dowling, 2001). North Bandung Area or Kawasan Bandung Utara, is a buffer plateau area covering four main areas, namely Bandung City, Bandung Regency, West Bandung Regency and Cimahi City. The area which has land contours at an altitude of 750 to 1,000 meter above sea level. This area has an important role as a water catchment and some of its areas are protected areas

North Bandung Area, is a buffer plateau area that covers four main areas, namely Bandung City, Bandung Regency, West Bandung Regency and Cimahi City. The area which has land contours at an altitude of 750 to 1,000 meter above sea level. This area has an important role as a water catchment and some of its areas are protected areas (Afandi, 2014). Referring to the Regional Regulation of West 
Java Province No.1 of 2008 concerning Control of Spatial Utilization of the North Bandung Area, one of its functions is to direct the development of the tourism sector, especially in ecotourism, agro-tourism, educational tourism and sports tourism.

Djuanda Forest Park has become a protected area whose space is used for tourism activities. Spatial utilization in North Bandung area is also supported by the Local Government policy direction set out in the West Java Provincial Regulation No. 25 of 2008 concerning Management of Djuanda Forest Park. Local regulations make it clear that tourism is one of the activities in the protected area of North Bandung. Djuanda Forest Park consists of three areas, namely Area Pakar, Maribaya, and Curug Dago, which stretches from Dago Pakar to Maribaya Lembang (Arief, 2013).

Djuanda forest park is part of the Bandung basin area, which has a historical background that intimately related to ancient times until now. Various relics found show that this area is a witness to the development of the city of Bandung since the beginning of the ancient lake. Geologically, this region experienced changes caused by natural turmoil over a long period during the process of formation of the universe. This protected area is the largest park ever built by the Dutch East Indies Government named Pulosari Protection Forest with an area of 590 Hectares.

As a nature conservation area and tourism destination, TAHURA managers should maintain tourist attractions, conserve natural resources and meet visitor satisfaction. Due to these factors, tourists are encouraged to visit this area so that tourism activities can be sustainable (Waluya, 2016). Sustainable tourism itself, defined as all forms of development, management and tourism activities by ensuring long-term protection of natural, cultural and social resources and contributing positively to community welfare (Eagles et al., 2002).

One strategy for achieving sustainable tourism in protected areas is by implementing a visitor management strategy. Managing visitors is one important way to manage the impact of tourism on the environment, especially its link between tourism activities in protected areas and socio-cultural and economic environments (Peter Mason, 2005). It is a tool and control that is widely used by several destinations in managing the flow of visitors, either by limiting the number of visitor according to capacity, or the spread of visitors. UNWTO (2015) proposed fundamental issues in managing tourism destinations and their indicators that can help measure those issues, including the intensity of destination use, the density of the use of tourist facilities, and the design of the carrying capacity.

Tourists who come to TAHURA have various reasons, including the quality of the destinations, tourist facilities, services, and tourist attractions in each area. Tahura is an alternative to outdoor tourism that is in great demand by Bandung residents, even tourists from outside the city. During the Covid-19 pandemic, TAHURA's management had imposed restrictions on the number of visitors and tourist activities by implementing a reservation system. Although the level of visits during weekdays is relatively controlled, there are often long queues on weekends or holidays even before operating hours open. The management has tried to provide the best service during tourists visiting TAHURA. Such as providing tour guide services and wheelchair facilities for the convenience of visitors. Nevertheless, visitor education about protected areas through information boards or other media is still not optimal. Other conditions, some tourism activities are still not well spread 
and supporting facilities are inadequate. This condition can affect satisfaction and visitor perception.

The success of visitor management strategies undertaken by the management of nature-based tourism destinations depends on how visitors felt perceived (Daily et al., 1997). The perception of tourists becomes input and evaluation in improving nature-based tourism destinations' facilities and services (Alessa et al., 2003; Daily, 2000; Schnurr \& Holtz, 1998). Tourist behaviour can indirectly be influenced by the quality of the environment of tourism destinations, on the other hand, tourists can directly influence the quality of the environment of tourism destinations based on their behaviour (Pendleton et al., 2001). The main variables to measure tourist perceptions of the tourism destination environment, such variables include awareness, opinion, and level of tourist satisfaction (Petrosillo et al., 2007)

A destination must be able to improve its quality to obtain a positive perception. Forming a positive perception of visitors is one of the keys to ensuring the development of a tourist destination (Ismayanti, 2010). Perception is a perspective, actions and images that a person gives to something in his environment, whether positive or negative (Murianto, 2014). In creating a positive perception, a tourism destination is required to meet the needs and desires of visitors and provide tourist experience (Pitana \& Gayatri, 2005). The management of a destination depends on how they are perceived by the wider community. Therefore, in improving the quality of destination management, perceptions from visitors are needed (Daily, 2000).

Previous research on visitor management and protected areas states that one way to reduce the negative impact of natural damage due to tourism activities is to implement a visitor management strategy (Hall \& Arthur, 1996; P Mason, 2003; Pearce, 1989). Several researchers have focused on a community approach in evaluating the application of visitor management. Mason (2005) states that the implementation of visitor management does not only require the application of "Hard" and "Soft" but also requires the experience of tourists in their behaviour, however this study does not explore from the perspective of tourists' opinions on the policies made. Studies on tourists' perceptions of protected areas have been carried out, such as research by Petrosillo et al. (2007) which is located in the marine area as a protected area, Study conduct by Salim et al. (2019) examines the public perception of nature as protected area. However, studies on tourist perceptions of the application of visitor management strategies in protected areas are still very limited. For this reason, this study tries to explore tourists' perceptions of the implementation of visitor management strategies in north Bandung protected areas by taking the location in Djuanda Forest Park.

\section{METHODOLOGY}

This research was conducted at Djuanda Forest Park's tourist destination as a protected area in North Bandung. Data collection was carried out by distributing questionnaires and personal interviews to visitors who had visited Djuanda Forest Park. The questionnaire was arranged in a structured manner divided into several categories: respondent characteristics, respondent experience, visitor awareness of protected areas, visitor satisfaction, and visitor perceptions on the implementation of Visitor Management Strategies (VMS). There are five alternative answer choices 
on the questionnaire, and some questions are given open answer options to strengthen quantitative answers.

The tourist perceptions and satisfaction Djuanda forest park are then given an assessment using a Likert scale from negative with a score of 1 (one) to the most positive with a score of 5 (five) to facilitate statistical analysis. The questionnaires were distributed to 101 respondent, which out of the target of 100 questionnaires and all respondents had visited Tahura. The data obtained were then analyzed by descriptive analysis method aimed to find out the causal factors and describing the research variables.

\section{RESULTS}

Djuanda Forest Park, geographically located at 107030 'BT and 60 52' LS and is the site of the Cikapundung River and Citarum River Basin. Administratively Duanda Forest Park is located in the area of Bandung Regency (Ciburial Village), West Bandung Regency (Mekarwangi Village, Cibodas Village, Langensari Village, and Wangunharja Village), and Bandung City (Dago Village). The Management is under the Regional Technical Implementation Unit of the West Java Province through the Central Forest Park Management Center. Based on history, Djuanda Forest Park is the first Forest Park in Indonesia which was initiated by President Soeharto and coincided with the date of birth of West Java Heroes Ir. H. Djuanda. Initially, it is known as the Mount Pulosari Protection Forest and Curug Dago Tourism Park. Physical conditions in Tahura Forest Park is divided into physiographic, climatic, stratigraphic, and ecological conditions. A detailed explanation of the physical condition is as follows:

a. Physiography

Tahura located on three borders of the administrative region has experienced changes caused by natural phenomena during a long period of forming the universe. The physiography is included in the Bandung Zone (BandungTangkubanparahu-Citatah-SagulingRegion). Regional Geomorphology of the Great Forest Park area Ir. H. Djuanda is located in the central volcanic units (Mount Palasari, Mount Manglayang, and Mount Bukit Tunggul) and extrusive volcanic units (Tangkubanparahu and the Lembang Fault).

b. Climate

Tahura has a tropical climate humid which was identified as a wet period between October-March and relatively dry in June-September with humidity of $70-90 \%$ and rainfall of 3000-4500 mm/year. Weather in Taman Hutan Raya Ir. H. Juanda is influenced by seasonal circulation patterns, the regional topography of West Java, and the Bandung plain topography's elevation. This makes the weather in the Forest Park Raya Ir. H. Juanda is different from other regions in West Java.

c. Stratigraphy

Forest Park Area Ir. H. Djuanda is controlled by the Lembang Fault which has east-west straightness with a downward movement of faults. Characteristics of geological diversity in the Great Forest Park area Ir. H. Djuanda is dominated by quarterly volcanoes that start at Mount Sunda Purba to Mount Tangkubanparahu. Besides, there are outcrops of igneous rock such as basalt lava and burly column structures associated with waterfalls, and hills. 


\section{d. Ecological}

Ecological Conditions in Forest Park Raya Ir. H. Djuanda is a Riparian Ecosystem located at an altitude of 770 to 1330 asl. Meanwhile, soil conditions in THRD are dominated by Andosol soils with high fertility.

Biodiversity in Djuanda Forest Park is mixed vegetation covering an area of $526,98 \mathrm{Ha}$. Types of flora from within and outside the country can be found in the area Arboretum (collection of plants), the area has an area of 30 hectares inhabited by 40 families, 112 species. For tree species in Forest Park Raya Ir. H. Djuanda includes Mexican Pine, Ugandan Mahogany, Eucalyptus, Sausage, Sumatran Pine, Sulawesi Bayur, Honduran Cedar, Cengal Pasir, Tide, Saninten, Kaliandra, Angsana, and others. As for the types of fauna found in the Forest Park area of Ir. H. Djuanda includes primates and birds, including Kera Ekor Panjang, Burung Kacamata, Perejak Jawa, Cinenen Pisang, Bongol Jawa, Jalak Suren, Perkutut Jawa, Elang Ular Bido, Cucak Kutilang. Also, there are deer that are maintained and managed in the area

\section{Tourist Profile \& Characteristic}

Respondents in this study can be considered to be a representation of the total tourist population who visited Djuanda Forest park as a protected area in the North Bandung Area. In order to obtain data about the profile of tourists it is necessary to ask questions related to the respondent's socio demographic (gender, age, place origin, education, occupation). The following Table is the respondent's profile and characteristics data.

Table 1. Tourist Profile In Tahura North Bandung Protected Area

\begin{tabular}{|r|l|r|}
\multicolumn{2}{|c|}{ Variable } & \multicolumn{1}{c|}{ Percentage \% } \\
\hline No & Gender & 55,4 \\
\hline & Male & 44,6 \\
\hline & Female & \\
\hline 2 & Age & 44,6 \\
\hline & $20-30$ Yo & 29,7 \\
\hline & $31-40$ Yo & 15,8 \\
\hline & $41-50$ Yo & 10,9 \\
\hline & $>50$ Yo & \\
\hline 3 & Place Origin & 70,3 \\
\hline & Bandung & 12 \\
\hline & Jabodetabek & 6 \\
\hline & Sumatra & 11,7 \\
\hline & Other & \\
\hline 4 & Education & 19,8 \\
\hline & SMA & 4,4 \\
\hline & Diploma & 26,7 \\
\hline & S1 & 42,6 \\
\hline & Master Degree & 6,9 \\
\hline & Doctorate program &
\end{tabular}




\begin{tabular}{|l|l|r|}
5 & Occupation & \\
\hline & Government Staff & 25,7 \\
\hline & Private & 29,7 \\
\hline & Student & 29,7 \\
\hline & Other & 14,7 \\
\hline
\end{tabular}

The results of the questionnaire above can be seen by male respondents outnumbered females with a percentage of $55.4 \%$ with the most age range classes at the age of 31-40 years. The tourists are mostly coming from Bandung citizens with $70.3 \%$ of respondents and second, come from Jabodetabek (Jakarta Bogor Depok Tangerang Bekasi) which is close to West Java province. Most people surveyed $42.6 \%$ had a master degree and bachelor degree background of $26.7 \%$ with the largest proportion of jobs being students and private employees, each of whom had a magnitude of $29.7 \%$

Besides, the characteristic of Djuanda Forest Park (Tahura) tourists can be identified through the frequency of visits, average expenditure, people invited during the visit and sources of information about Tahura. In detail we can observe in the following Table:

Table 2 Tourist Characteristic

(Respondents $\mathrm{n}=101$ )

\begin{tabular}{|c|c|c|c|}
\hline No & Description & $\begin{array}{l}\text { Alternative } \\
\text { Answer }\end{array}$ & $\begin{array}{c}\text { Percentage } \\
\quad(\%)\end{array}$ \\
\hline \multirow[t]{3}{*}{1} & Frequent of Visit on & $1 \mathrm{x}$ & 40,6 \\
\hline & & $2 x$ & 18,8 \\
\hline & & $3 x$ & 40,6 \\
\hline \multirow[t]{3}{*}{2} & $\begin{array}{l}\text { Spending Money } \\
\text { per visit }\end{array}$ & $\begin{array}{l}<\mathrm{Rp} . \\
500.000\end{array}$ & 86,1 \\
\hline & & $\begin{array}{l}<\mathrm{Rp} . \\
1.000 .000\end{array}$ & 9,9 \\
\hline & & $\begin{array}{l}>\mathrm{Rp} . \\
3.000 .000\end{array}$ & 4 \\
\hline \multirow[t]{4}{*}{3} & Companion & Alone & 3 \\
\hline & & Friend & 50,5 \\
\hline & & Family & 45,5 \\
\hline & & Partner & 1 \\
\hline \multirow[t]{4}{*}{4} & $\begin{array}{l}\text { Source of } \\
\text { Information }\end{array}$ & Friend & 63,4 \\
\hline & & Internet & 26,7 \\
\hline & & Newspaper & 3 \\
\hline & & Other & 6,9 \\
\hline
\end{tabular}




\section{Tourist Awareness of Taman Hutan Raya Djuanda (Tahura ) North Bandung Protected Area}

To get the level of tourist awareness of the protected area in north Bandung, questions are asked regarding tourists' perception in protecting the preserved area. This awareness can be measured through their opinion about the condition of the natural environment, the management carried out by Tahura on environmental quality and their opinion concerning the limited number of visits. A high percentage of respondents $(87,1 \%)$ of visitors are aware of Tahura as a Protected Area in North Bandung. The tourist's opinion regarding the environmental preservation in the Tahura, as much as $58,4 \%$ of respondent stated in good and excellent. There are $32,7 \%$ state the preservation efforts were on average. The environmental quality education carried out by management is still very low with $38,6 \%$ answering good and 5,9\% very good. More than half of the respondents stated that Tahura's management work program related to environmental education is still lacking. In terms of utilizing insurance costs on the entrance fee, most tourists agree to pay, with $60,5 \%$ of the respondents agreeing and strongly agreeing. Concerning the limitation of tourist numbers due to preserving the environment, $62.4 \%$ of respondents agreed and strongly agreed to preserve the environment although disrupting their tourism activities. in general, the tourist's are aware that Tahura as tourism protected area, but visitors assess conservation efforts undertaken by management Tahura especially in educating visitors still need to be improved

Table 3. Tourist Awareness of Environment In Tahura as North Bandung Area

(Respondents $\mathrm{n}=101$ )

\begin{tabular}{|c|c|c|c|}
\hline No & Question & $\begin{array}{l}\text { Alternative } \\
\text { Answer }\end{array}$ & $\%$ \\
\hline \multirow[b]{2}{*}{1} & \multirow{2}{*}{$\begin{array}{l}\text { Tourist Awareness of Tahura as } \\
\text { Protected Area }\end{array}$} & Yes & 87,1 \\
\hline & & No & 12,9 \\
\hline \multirow{5}{*}{2} & \multirow{5}{*}{$\begin{array}{l}\text { Tourist opinion of the Condition of } \\
\text { environmental preservation in the } \\
\text { Tahura, North Bandung Protected Area }\end{array}$} & Not Very Good & 1 \\
\hline & & Not Good & 7,9 \\
\hline & & Average & 32,7 \\
\hline & & Good & 50,5 \\
\hline & & Very Good & 7,9 \\
\hline \multirow{5}{*}{3} & \multirow{5}{*}{$\begin{array}{l}\text { Environmental quality education carried } \\
\text { out by the management of Tahura North } \\
\text { Bandung Area }\end{array}$} & Not Very Good & 3 \\
\hline & & Not Good & 11,9 \\
\hline & & Average & 40,9 \\
\hline & & Good & 38,6 \\
\hline & & Very Good & 5,9 \\
\hline \multirow{5}{*}{4} & \multirow{5}{*}{$\begin{array}{l}\text { Visitor opinion about Insurance coverage } \\
\text { approved by the visit and recreational } \\
\text { activities in the Tahura, North Bandung } \\
\text { Area }\end{array}$} & Not Very Good & 3 \\
\hline & & Not Good & 14,9 \\
\hline & & Average & 21,8 \\
\hline & & Good & 29,8 \\
\hline & & Very Good & 30,7 \\
\hline 5 & & Not Very Good & 4 \\
\hline
\end{tabular}




\begin{tabular}{|l|l|l|l|} 
& & Not Good & 14,9 \\
\cline { 3 - 3 } $\begin{array}{l}\text { Visitor opinion if the management } \\
\text { applies restrictions recreational activities } \\
\text { on visiting Tahura, North Bandung Area }\end{array}$ & Average & 18,8 \\
\cline { 3 - 4 } & & Good & 41,6 \\
\cline { 2 - 3 } & Very Good & 20,8 \\
\hline
\end{tabular}

In addition to closed questions above, also filed related public opinion efforts should be made by management in conserving Tahura region. Most of the respondents stated the management could provide education for visitors, determine each tourist zone's carrying capacity, improve pedestrian areas, increase trash bin facilities, and carry out educational programs such as planting trees. In general, it can be seen that the public are aware Tahura as a protected area which must be maintained and preserved, but respondent assess conservation efforts undertaken by management Tahura especially in educating visitors still need to be improved.

\section{Tourist Attraction and Environmental impacts in Taman Hutan Raya Djuanda (Tahura) North Bandung Protected Area}

Tourism activities have positive and negative impacts on the environment. This study aims to determine the tourist perception of the impact of tourism on the ecosystem through the implementation of a visitor management strategy. Most of the tourist activities carried out in Djuanda Forest Park are trekking, enjoying the waterfall, and relaxation.

These activities directly or indirectly impact soil damage, water condition, flora and fauna, and the landscape. The study results show that the relaxation activity is very potential for environmental destruction compared to trekking or enjoying waterfalls activities. Relaxation activities with many kinds of different forms can trigger the behaviour of tourists who are less responsible such as waste production, density in certain zones, and natural damage. The time spent by tourists in relaxation largely determines the potential for environmental damage, while tourism activities' least impact is damage to the landscape. The detail of tourist attraction and environmental impact can be seen in the table below:

Table 4. Tourist Attraction and Environmental Impact

\begin{tabular}{|r|l|r|r|r|r|r|}
\hline No & \multicolumn{1}{|c|}{ Tourism Activity } & $\begin{array}{r}\text { Very } \\
\text { Little }\end{array}$ & Little & Neutral & Much & $\begin{array}{r}\text { Very } \\
\text { Much }\end{array}$ \\
\hline 1 & Spent activity on trekking & 3 & 16,8 & 37,6 & 32,7 & 9,9 \\
\hline 2 & Activity in Water Fall & 4 & 14,9 & 37,7 & 34,7 & 8,9 \\
\hline 3 & Activity on relaxation & 0 & 7,9 & 26,7 & 50,5 & 14,9 \\
\hline 4 & $\begin{array}{l}\text { Impact tourism activity soil } \\
\text { damage }\end{array}$ & 2 & 10,9 & 45,5 & 33,7 & 7,9 \\
\hline 5 & $\begin{array}{l}\text { Impact tourism activity on water } \\
\text { damage }\end{array}$ & 2 & 12,9 & 45,5 & 33,7 & 5,9 \\
\hline
\end{tabular}




\begin{tabular}{|c|l|r|r|r|r|r|}
\cline { 2 - 6 } 6 & $\begin{array}{l}\text { Impact tourism Activity on flora \& } \\
\text { fauna }\end{array}$ & 1 & 14,9 & 46,5 & 31,7 & 5,9 \\
\hline 7 & Impact tourism activity to landscape & 2 & 11,9 & 52,5 & 25,7 & 7,9 \\
\hline
\end{tabular}

Djuanda Forest Park has unique natural tourism potential, supported by a variety of flora and fauna. However, this circumstance needs to be balanced with the maintenance and enhancement of visitor facilities. Some of the tourism objects that need to be improved are the Dutch Cave area, waterfall tourist attractions or Curug Omas, walking paths and other zones.

As a tourist destination, Djuanda Forest Park strives to provide the best service to create tourist satisfaction. The perception of visitor management strategies' implementation cannot be separated from their satisfaction during their visit. The Djuanda Forest Park management aimed to preserve protected areas and expected to be able to manage tourist attraction by creating sustainable tourism (Candrea \& Ispas, 2009). Satisfaction aspects assessed in strengthening visitor perceptions include analysis through prices, variations in prices and products offered, natural beauty and tourist attractions, air and water quality, service availability, friendliness, speed and employee response to guest complaints. The results of the research data recap show that an average level of tourist satisfaction is quite high, at $67 \%$. In general, natural conditions as a tourist attraction are excellent. However, the quality of service still needs to be improved, especially in terms of handling complaints and speed of service. The questionnaire summarisations on visitor satisfaction can be seen in Table 6 below:

Table 5 Tourist Satisfaction

\begin{tabular}{|c|c|c|c|c|c|c|}
\hline \multirow[b]{2}{*}{ No } & \multirow[b]{2}{*}{ Question } & \multicolumn{4}{|c|}{ Respondents $(\mathrm{n}=101)(\%)$} & \multirow[b]{2}{*}{$\begin{array}{c}\text { Very } \\
\text { satisfied }\end{array}$} \\
\hline & & $\begin{array}{c}\text { Very } \\
\text { unsatisfied }\end{array}$ & Unsatisfied & Neutral & Satisfied & \\
\hline 1 & Price offered & 0 & 8 & 49 & 34 & 10 \\
\hline 2 & $\begin{array}{l}\text { Variety of price and } \\
\text { product offering }\end{array}$ & 0 & 19 & 52 & 27 & 3 \\
\hline 3 & $\begin{array}{l}\text { The Beauty of nature and } \\
\text { attraction }\end{array}$ & 0 & 0 & 26 & 51 & 24 \\
\hline 4 & $\begin{array}{l}\text { The Quality of air dan } \\
\text { water }\end{array}$ & 0 & 0 & 19 & 48 & 34 \\
\hline 5 & $\begin{array}{l}\text { Service availability } \\
\text { (Customer Service) staff } \\
\text { in all areas of Tahura }\end{array}$ & 1 & 24 & 52 & 19 & 5 \\
\hline 6 & $\begin{array}{l}\text { The friendliness of the } \\
\text { staff }\end{array}$ & 1 & 17 & 52 & 25 & 6 \\
\hline 7 & The speed of service & 1 & 18 & 57 & 21 & 4 \\
\hline 8 & $\begin{array}{l}\text { Staff responses to visitor } \\
\text { complaints in Tahura }\end{array}$ & 1 & 22 & 57 & 18 & 3 \\
\hline
\end{tabular}

Other opinions related to matters need to be improved for tourist satisfaction, there was a lack of information presented on the website which is still very least 
and has not been updated. In addition, in terms of service, Djuanda Forest Park still lacks staff in serving visitors. Mostly officers are only found at the entrance gate, where there must be a person serving at each counter or certain point. The condition of accessibility that is still not completely good, it has become concerned since it can facilitate mobilization and exploration throughout the Tahura region. On the other side, the existence of tour guides, loyalty programs and promotions also need to be developed. Brochures and information boards to make it easier for visitors are also lacking.

\section{DISCUSSION}

This study was designed to determine visitors' perceptions in the implementation of the visitor management strategy on protected areas to support sustainable tourism in Djuanda Forest Park, Bandung. Most respondents with a background in education and stable employment indicate that the visitors' level of awareness will show a very well protected area. This should be followed by a program from the management that involves visitors to take part in nature conservation such as tree planting programs or waste reduction so that visitors have recreation and contribute to sustainable tourism.

The high tourist activity at a specific location in the protected area can impact environmental degradation. The most favourite tourist activity at Djuanda Forest Park such as relaxation and trekking tour done in a relatively longer time than other activities could potentially damage the soil, water and flora and fauna. Therefore, it is necessary to expand tourism areas evenly so that the distribution of visitors is more balanced in all areas. The management needs to consider more zoning and managing the supply by imposing restrictions on the number of visitors and the length of visiting hours considered to conserve natural resources (Candrea \& Ispas, 2009).

The management of Djuanda Forest Park has implemented a visitor management strategy in the form of a hard and soft approach. Hard approach or physical development and 'soft' through education and interpretation as proposed by Mason (2005). However, the perception of tourists in these two aspects is still not optimal. Management needs to emphasize managing the visitor experience. Overall, the measurement of visitor perceptions on the implementation of the visitor management strategy analyzed through the intensity of destination use, ease of access and planning for carrying capacity still needs to be improved. The existing tourism infrastructure along the Djuanda Forest Park area needs to be equipped and requires good maintenance. Such as the procurement of tourist guide boards, the number of bins, the arrangement of tourist attractions, and the determination of the amount of carrying capacity. There are two purposes of managing protected areas from the administrator side: minimizing the environmental impact and increasing tourism visits. Candrea and Ispas (2009) state that this can be done in three ways, first, managing the tourism supply by expanding the area of tourist activity to balance the distribution of people. Second, management can arrange the demand due to the number of people visit. Third, by increasing resource capacity on the importance of sustainable tourism and impact management.

The perception of visitor management is inseparable from visitor satisfaction and the quality of service they get when they visit. Most of the respondents were residents who had made previous visits. Many of these respondents still complained 
about the lack of maintenance of tourist areas and packaging of tourism products. for instance, in the Dutch cave area, trekking paths, and public facilities. In terms of visitors, satisfaction and experience are very important. Therefore, management needs to improve service quality and package tourism products more attractive. These will lead to a tourist experience to be so that visitors feel satisfied and return to Djuanda Forest Park

\section{CONCLUSION}

The biggest challenge in managing a protected area as a tourist destination is to minimize the negative impact of tourism activities and conserve natural resources. A visitor management strategy is essential to keep Protected Areas sustainable. Through this research, tourists' perceptions of the application of visitor management strategies can be investigated and become information and evaluation materials in enhancing the quality of management. Overall, the perception of tourists on the application of visitor management strategies is quite good. It is directly proportional to the level of satisfaction they get when visiting. However, the key to a tourist destination's success is inseparable from the tourist experience of the products and services provided.

For this reason, improving the tourist experience through education and services is significant. Several things need to be developed by the management regarding the visitor management strategy, such as the visitor flow so that all areas can be visited evenly, adding information boards that educate visitors and the quality of service. Sustainable tourism management requires strategic steps both planning and evaluating, on an ongoing basis by considering the needs of tourists and nature conservation. This research was limited in a short period and one destination and focused on some implementation of visitor management strategy. Future studies expected to explore the experience of tourists in the protected area

\section{REFERENCES}

Afandi, M. N. (2014). Implementasi Kebijakan Pembangunan di Kawasan Bandung Utara Dalam Perspektif Pembangunan Berwawasan Lingkungan. Jurnal Ilmu Administrasi Bisnis, 11(2).

Alessa, L., Bennett, S. M., \& Kliskey, A. D. (2003). Effect of Knowledge, Personal Attribution and Perception of Ecosystem Health on Depreciative Behaviours in The Intertidal Zone of Pacific Rim National Park and Reserve. Journal of Environmental Management, 68(2).

Arief, A. M. R. (2013). Pengembangan Aktivitas Wisata di Taman Hutan Raya Ir. H. Djuanda Bandung Jawa Barat. Jurnal Sorot, 8(2), 1-190.

Candrea, A. N., \& Ispas, A. (2009). Visitor Management, a Tool for Sustainable Tourism Development in Protected Areas. Bulletin of The Transilvania University of Brasov, 2(51), 131-136.

Daily, G. C. (2000). Management Objectives for the Protection of Ecosystem Services. Environmental Science and Policy, 3(6), 333-339. https://doi.org/https://doi.org/10.1016/S1462-9011(00)00102-7

Daily, G., Matson, P. A., Costanza, R., Nabhan, G. P., \& Lubchenco, J. (1997). Nature' s Services Nature's Services: Societal Dependence On Natural Ecosystems. Scientist. 
Dowling, R. K. (2001). Environment and tourism by Andrew Holden. Introduction to environment series, Routledge, London, 2000. No. of pages: 225. Price? (paperback). ISSN 0-415-20718-5. International Journal of Tourism Research. https://doi.org/10.1002/jtr.339

Eagles, P. F. J., Mccool, S. F., \& Haynes, C. D. (2002). Sustainable Tourism in Protected Areas Guidelines for Planning and Management. In World. https://doi.org/10.2305/IUCN.CH.2002.PAG.8.en

Hall, C. M., \& Arthur, S. M. (1996). Heritage Management in Australia and New Zealand: The Human Dimension. Oxford University Press.

Ismayanti. (2010). Pengantar Pariwisata. PT Gramedia Widiasarana Indonesia.

Mason, P. (2003). Tourism Impacts, Planning and Management. Butterworth Heinemann.

Mason, P. (2005). Visitor Management in Protected Areas: From "hard" to "soft" Approaches? Current Issues in Tourism, 8(2-3), 181-194.

Mason, Peter. (2005). Visitor management in protected areas: From "hard" to "soft" approaches? Current Issues in Tourism, 8(2-3), 181-194. https://doi.org/10.1080/13683500508668213

Murianto, M. (2014). Potensi dan Persepsi Masyarakat Serta Wisatawan Terhadap Pengembangan Ekowisata di Desa Aik Berik, Lombok Tengah. Jurnal Master Pariwisata, 1(1).

Pearce, D. G. (1989). Using the Literature on Tourism: A Personal Perspective. Emerald Insight, 44(3).

Pendleton, L., Martin, N., \& Webster, D. G. (2001). Public Perceptions of Environmental Quality: A Survey Study of Beach Use and Perceptions in Los Angeles County. Marine Pllution Bulletin, 42(11), 1155-1160.

Petrosillo, I., Zurlini, G., Corliano, M. E., Zaccarelli, N., \& Dadamo, M. (2007). Protected Area Tourist Perception of Recreational Environment and Management in a Marine Protected Area. Landscape and Urban Planning, 79(1), 29-37.

Pitana, I. G., \& Gayatri, P. G. (2005). Sosiologi Pariwisata. Andi Offset.

Salim, A., Hidayat, S., Wulandari, R., Pratama, C. D., \& Ichwani, S. N. (2019). A Green Scenario for Sustainable Landscape Planning: The Case Study in Sintang Regency, West Kalimantan Province. IOP Conference Series: Earth and Environmental Science, 1-9.

Schnurr, J., \& Holtz, S. (1998). The Cornerstone of Development: Integrating Environmental, Social, and Economic Policies. International Development Research Centre.

UNWTO. (2015). Tourism highlights.

Waluya. (2016). Pengaruh Elemen Ekowisata Terhadap Keputusan Berkunjung Wisatawan Ke Taman Hutan Raya Ir. H. Djuanda. Tourism and Hospitality Essentials Journal, 6(1). 